application of all the learning styles instructors can help students achieve this goal, gain greater confidence in their abilities (affective dimension), and simultaneously gain a wider range of skills (cognitive dimension).

\section{References}

Anderson, J.A. 1995. "Toward a Framework for Matching Teaching and Learning Styles for Diverse Populations." In The Importance of Learning Styles: Understanding the Implications for Learning, Course Design, and Education, ed. R.R. Sims and S.J. Sims. Westport, CT: Greenwood Press.

, and M. Adams, 1992. "Acknowledging the Learning Styles of Diverse Student Populations: Implications for Instructional Design." In Teaching for Diversity, ed. L.L.A. Border and N. Van Note Chism. New Directors for Teaching and Learning, No. 49. San Francisco: Jossey-Bass.

Baxter, M. B. 1989. "Gender Differences in Cognitive Development: An Analysis of Cognitive Complexity and Learning Styles." Joumal of College Student Development 30(3): 213-20.

Belenky, M.F., B.M. Clinchy, N.R. Goldberger, and J.M. Tarule. 1986. Women's Ways of Knowing: The Development of Self, Voice, and Mind. New York: Basic Books. Claxton, C.S., and P.H. Murrell. 1987. Learning Styles: Implications for Improving Edu- cational Practices. College Station, TX: Association for the Study of Higher Education.

Harb, J.N., R.E. Terry, P.K. Hurt, and K.J. Williamson. 1995. Teaching Through the Cycle: Application of Learning Style Theory to Engineering Education at Brigham Young University. 2nd ed. Provo, UT: Brigham Young University Press.

Hickcox, L.K. 1995. "Learning Styles: A Survey of Adult Learning Style Inventory Models." In The Importance of Learning Styles: Understanding the Implications for Learning, Course Design, and Education, ed. R.R. Sims and S.J. Sims. Westport, CT: Greenwood Press. . 1991. "Kolb's Experiential Learning Theory: An Historical Review and its Effects in Higher and Adult Education1971-1991." In An Historical Review of Kolb's Formulation of Experiential Learning Theory. Ph.D. diss. Oregon State University.

Hyman, R., and B. Rosoff. 1984. "Matching Learning and Teaching Styles: The Jug and What's in It." Theory Into Practice 23(1): 35-43.

Kolb, D.A. 1985. Learning Style Inventory. Boston: McBer and Co.

- 1984. Experiential Leaming: Experience as the Source of Learning and Development. Englewood Cliffs, NJ: Prentice-Hall.

Miller, J.B. 1986. Toward a New Psychology of Women. 2nd ed. Boston: Beacon Press.

Perry, W.G., Jr. 1970. Forms of Intellectual and Ethical Development in the College Years: A Scheme. New York: Holt, Rinehart, and Winston.

_. 1981. "Cognitive and Ethical Growth:
The Making of Meaning." In The Modem American College, ed. A.W. Chickering. San Francisco: Jossey-Bass.

Sims, R.R., and S.J. Sims. 1995. "Learning Enhancement in Higher Education." In The Importance of Learning Styles: Understanding the Implications for Learning, Course, Design, and Education, ed. R.R. Sims and S.J. Sims. Westport, CT: Greenwood Press.

Svinicki, M.D., and N.M. Dixon. 1987. "The Kolb Model Modified for Classroom Activities." College Teaching 35(4):141-46.

Tinto, V. 1993. Leaving College: Rethinking the Causes and Cures of Student Attrition. 2nd ed. Chicago and London: University of Chicago Press.

\section{About the Authors}

Richard L. Fox is an assistant professor of political science at Union College in Schenectady, New York. He is the author of Gender Dynamics in Congressional Elections (Sage, 1997).

Shirley A. Ronkowski, Ph.D., is an instructional Specialist in the Office of Instructional Consultation and Academic Coordinator for the campus-wide Teaching Assistant Development Program at the University of California, Santa Barbara. Her published articles, book chapters, and conference papers focus on instructional design, the scholarship of teaching, cooperative learning, and instructional technology for both current and future faculty.

\title{
Numbers? Borrinnnggg!!!
}

\section{William I. Buscemi, Wittenberg University}

How big is government anyway? Compared to what? How much does it spend? How many people work for it? Doing what? Should we cut welfare? Social Security? Should we reduce taxes? Balance the budget? Reduce the national debt? These questions dominate public discussion of politics, and should, it seems, figure heavily in any course on American government. Indications are, however, that they do not.

Students are more turned off from politics today than at any time since the 1950s (see Mann 1996). One reason for this lack of interest might be that the pressing issues of today, e.g., structural unemployment, welfare reform, and budget deficits, call for a different sort of understanding than did the issues of the $1960 \mathrm{~s}$ and 1970 s, e.g. school segregation, the Vietnam war, and Watergate. What appears as apathy and cynicism may be due in part to a lack of relevant conceptual tools with which to comprehend and judge important political events. To grasp today's issues one needs a sense of numbers; unfortunately, many students today would, if pressed, be hard put to describe the difference between a million and a billion. Why are students so innumerate with regard to the large numbers that figure into politics? I would suggest three factors that contribute to the problem. First of all, politicians, whose rhetoric fills much of the space available for political communication, have little in- centive to provide, and much reason to blur and evade, clear information concerning the magnitudes most relevant to the issue at hand. Rather than speak directly of unemployment rates or deficit figures, for instance, politicians often make reference to some incremental change over a time span selected to show themselves to advantage. Ross Perot, for all his faults, is to be commended for his attempts to provide, in clear and direct form, basic figures concerning such problems as the national debt. A second factor contributing to students' lack of interest in quantitative data may be, paradoxically, our own insistence as teachers on the highest standards of rigor and precision. We tend to disparage the 
"quick and dirty" estimates that are often most useful and appropriate for dealing with the issues at hand. We fail to convey to students that, even in our own research, it is the rough estimate that usually precedes the controlled study, frames its significance, and provides the intuitive criteria for assessing its results.

When teaching, we too often reverse this sequence and attempt to equip students with sophisticated methodological tools for solving problems before they have been made to feel the importance and difficulty of the questions. We would do better to begin with rough numbers and bold comparisons, and hold the qualifications and refinements until later. Yet another factor contributing to student apathy concerning politics is, I believe, the failure of introductory textbooks in American government to provide significant and accessible data. Despite the plethora of slick and colorful graphics displaying all sorts of data, one senses that these are presented largely for their own sake, perhaps "to teach students to read charts and graphs" (or worse, to sell text books), and not because the data are significant, or integrally related to the text.

The kind of understanding that I argue for here is a sense of the important magnitudes, their relative proportions, and the place of one's own concerns within the whole. This sort of understanding is not exactly "quantitative"; it results less from the application of mathematical and methodological technique than from reliance upon the kind of intuition or "feel" that an artist has for shape and composition, or the educated layperson has for geographic locations or historical periods. Such intuitions, inexact though they may be, provide the parameters within which we wrestle with more local problems. This is the same sort of intuition that we use in our daily lives. When buying a car, we estimate our assets and calculate the trade-offs between cost and comfort; and when budgeting our time, we balance the importance of various claims against the limits of our own energies. Such rough and ready estimations underlie almost all of our understanding and decision making.

Will students be overwhelmed and confused when confronted with huge numbers, especially when they find that these are to be taken seriously and may even be on the exam? Maybe. But perhaps the opposite will occur. A sense of empowerment can come to students when they realize their ability to see large numbers in relation to one another, and to explore the correlations among them through rough but important calculations. Ask them to estimate, for example, what would happen if we really did turn swords into plowshares. How could they perform this calculation? First, have them take the amount that is spent each year by all nations on military items, which is nearly $\$ 1,000 \mathrm{~B}$ (U.S. Department of Commerce 1996, 354). ${ }^{1}$ Then tell them to divide this money among the world's poor, who number, let us say, $1 / 6$ of the world's population, or $1 \mathrm{~B}$ people. The result is that each poor person would get $\$ 1,000$ annually, a fantastic sum to those whose current yearly income is less than $\$ 100$ ! This is, of course, a problem much easier to solve arithmetically than politically, but it provides an interesting talking point and a sense of proportion.

How can we give students a feel for big numbers? Invariably, intuitions are anchored in familiar experience. Most Americans "feel" the distance of 100 yards as the length of a football field, and a gallon as the volume of a milk container; (meters and grams remain, unfortunately, mere abstractions). To impress upon students the difference between a million and a billion, we might try comparing these numbers to the length of the class room: if the whole length is a billion, then a million is a half inch or so; or, if a million is a penny, a billion is $\$ 10$. Once numbers are brought within the circle of student "familiars," data tend to lose their authoritative and mysterious quality. No longer must one rely so absolutely upon word from the experts, who alone have access to arcane sources. Importantsounding pronouncements concerning, for example, the national debt, can now be measured against one's own estimates. Here, too, is a corrective against the notorious power of statistics to "lie." Students will come to realize, when making their own calculations, that all such operations involve interpretation and construction, that it makes a difference whether you compare U.S. living standards to all nations or only to industrialized nations, and whether you measure debt growth over the last 4 years, or the last 14. Students will be better able to evaluate the interpretations of others, once they gain experience in formulating their own.

Where do we find those figures so important to achieving an understanding of major political issues? In my experience, the typical American government text book is of little help. Scanning three texts recently sent to me for possible course adoption-Janda, Berry, and Goldman (1993), Paterson (1996), and Edwards, Wattenberg, and Lineberry (1996) - I find little that is useful concerning, for instance, the federal budget. Two of the texts have small pie charts (Patterson 1996, 517; Edwards, Wattenberg, and Lineberry 1996, 375), which are not very informative because their expenditure categories are too vague, and their use of percentages rather than dollar figures prevents easy comparison with other relevant data. ${ }^{2}$ Indeed, much of the data presented in the typical text would qualify as "trivia," since they are unrelated to the sorts of context or comparisons which alone could convey their significance. The main source that I used to gather data for this article was the U. S. government publication Statistical Abstracts (1996), a surprisingly accessible, interesting, comprehensive compendium of census data and other records pertaining to a wide range of political, economic, and demographic issues. ${ }^{3}$

How big is government? Annual expenditures by all levels of American government are shown roughly in the following figures: (U.S. Department of Commerce 1996, 330). ${ }^{4}$

\begin{tabular}{lr}
\hline Federal & $\$ 1,600 \mathrm{~B}$ \\
State & $850 \mathrm{~B}$ \\
Local & $750 \mathrm{~B}$ \\
\hline Total & $\$ 3,200 \mathrm{~B}$ \\
\hline
\end{tabular}

What is the significance of these numbers? To get a sense of their importance we might compare them, first of all, to the nation's Gross Domestic Product, which is about 


\section{TABLE 1 \\ Total Tax Receipts as \% of GDP6}

Denmark 51.6

Sweden

51.6

Sweden

51.0

47.3

Czech Republic $\quad 47.3$

Belgium

Netherlands

Luxembourg

France

Poland

Austria

Greece

Italy

Norway

Hungary

Germany

Ireland

New Zealand

Canada

Spain

United Kingdom

Switzerland

Portugal

Iceland

Australia

Japan

United States

Turkey

Mexico

Source: OECD $(1997,46-47)$

$\$ 7,000$ B $(1996,443) .{ }^{5}$ We see then that the government spends almost half of all that the nation "earns" each year. Is that excessive? To pursue this question we could compare the percentage of GDP spent by government in the U.S. to that of other countries, as seen in the following table.

Table 1 indicates that the size of the U.S. government is, in proportion to its economy, smaller than that of nearly any other industrialized nation. A related question concerns the size of the national debt, which is about $\$ 5,000 \mathrm{~B}(1996,330){ }^{7}$ Is this excessive? Supply siders would say not, since it is less than the GDP. After all, a family or business thinks nothing of going into debt for amounts two to three times its annual salary or profits, particularly if borrowing enhances the prospects of future earnings, as do college tuition, factory equipment, or, in the case of government, highway construction. And what, by the way, is that awesome figure so often quoted, but which we never quite remember, namely "Each man, woman, and child's share of the national debt?" No problem: just divide the $\$ 5,000 \mathrm{~B}$ debt among $260 \mathrm{M}$ people, or roughly $1 / 4 \mathrm{~B}$, and you get $\$ 20,000$ per person: a little high, maybe, but close enough, and about the amount spent on a year of college! How does government spend its money? ${ }^{8}$ The federal government spends its half of all government money roughly as follows:

\begin{tabular}{lc}
\hline $\begin{array}{l}\text { Social Security, Medicare, } \\
\text { and federal employee } \\
\text { retirement }\end{array}$ & $\$ 750 \mathrm{~B}$ \\
$\begin{array}{l}\text { Interest on the national } \\
\text { debt }\end{array}$ & $250 \mathrm{~B}$ \\
$\begin{array}{l}\text { Defense } \\
\text { Welfare }\end{array}$ & $250 \mathrm{~B}$ \\
Other & $250 \mathrm{~B}$ \\
Total & $\frac{100 \mathrm{~B}}{\$ 1,600 \mathrm{~B}}$ \\
\hline
\end{tabular}

Students should understand that some of these expenditures, called "Entitlements," are more resistant to budget cuts than others, since they involve legal, contractual obligations. This is the case with the first two items on the above list. If the federal budget is to be reduced, therefore, cuts will most likely come from the other areas, which together make up only $\$ 600 \mathrm{~B}$ of the $\$ 1,600 \mathrm{~B}$ federal budget. This helps to explain why budget cuts involve such politically painful decisions.

How many people work for the government? Or, to put it more ideologically, what is the size of the "bureaucracy"? (The Council of State Governments 1996-97, table 7.14; U.S. Department of Commerce 1996, 346)..$^{9}$ The overall picture looks about like this:

\begin{tabular}{lr}
\hline $\begin{array}{l}\text { Federal employees } \\
\text { (including almost 2M }\end{array}$ & $5 \mathrm{M}$ \\
$\quad$ military) & \\
State employees & $5 \mathrm{M}$ \\
Local employees & $11 \mathrm{M}$ \\
$\quad$ (including 6M & \\
$\quad$ teachers) & \\
\hline Total & $21 \mathrm{M}$ \\
\hline
\end{tabular}

Is this too many? Compared to what? Comparing the number of government workers to the total
American work force, which we could roughly estimate to be $100 \mathrm{M}$ out of the $264 \mathrm{M}$ total population, the government workforce of $21 \mathrm{M}$ constitutes just a bit over $20 \%$, or 1 out of 5. Other relevant comparison would be to prior years, and to other countries (Wolff, et al. 1992, 197). ${ }^{10}$

One of the most powerful ways to present comparative data, given the natural human interest in recordsetting and competition between "us" and "them," is the rank-order list. It is perhaps not surprising, given the dependence of most publishers of textbooks or statistics on either government funding or genteel academic sensibilities, that such listings, with their potential for causing embarrassment, are rare. Even when all of the data required for such rankings are present, the actual listings are usually in alphabetical order-or some other innocuous pattern which serves to confound comparisons. With only a little effort, however, alphabetical tables can be converted to rank-order listings, as I have done in Table 2.

It would be interesting to compare incarceration rates to similar tables listing other socio-economic variables. Which states have the highest percentage of people in poverty? New Mexico and the District of Columbia top the list with $21 \%$ each. Which have the least poverty? Utah and Delaware with about $8 \%$ each (U.S. Department of Commerce 1996, 474). Which states have the highest rates of violent crime? That dubious distinction is shared by Florida and the District of Columbia $(1996,202)$. The least crime? North Dakota and Vermont. Which states have the most college graduates? Massachusetts and Colorado, while West Virginia and Kentucky have the fewest $(1996,161)$. And most interestingly, where does one's own state stand in the rankings?

Country-by-country comparisons are even more eye-catching than state comparisons, and it is unfortunate that, as social scientists, we teach so little material from this most obvious fund of data for constructing ready-made experimental tests. ${ }^{12}$ However rough, such comparisons are useful, at least as a first step, in evaluating our own institutions and policies. What is the popu- 


\section{TABLE 2 \\ Rates of Incarceration per 100,000 Population ${ }^{11}$}

\begin{tabular}{|c|c|c|c|}
\hline Wash. D.C. & 1,583 & Kentucky & 288 \\
\hline Texas & 636 & Tennessee & 277 \\
\hline Louisiana & 530 & Idaho & 258 \\
\hline Oklahoma & 508 & Indiana & 258 \\
\hline S. Carolina & 494 & Wyoming & 254 \\
\hline Nevada & 460 & Kansas & 249 \\
\hline Arizona & 459 & S. Dakota & 240 \\
\hline Georgia & 456 & Pennsylvania & 235 \\
\hline Alabama & 450 & New Mexico & 220 \\
\hline Michigan & 428 & Hawaii & 202 \\
\hline Mississippi & 408 & Washington & 201 \\
\hline Florida & 406 & Montana & 194 \\
\hline Maryland & 395 & lowa & 192 \\
\hline Virginia & 395 & Wisconsin & 187 \\
\hline Delaware & 393 & Rhode Island & 186 \\
\hline California & 384 & N. Hampshire & 177 \\
\hline Ohio & 377 & Oregon & 175 \\
\hline New York & 367 & Mass. & 171 \\
\hline Arkansas & 353 & Vermont & 168 \\
\hline Missouri & 338 & Nebraska & 159 \\
\hline N. Carolina & 322 & Utah & 155 \\
\hline Connecticut & 321 & Maine & 118 \\
\hline Alaska & 317 & W. Virginia & 106 \\
\hline Illinois & 310 & Minnesota & 100 \\
\hline New Jersey & 310 & N. Dakota & 78 \\
\hline Colorado & 289 & & \\
\hline
\end{tabular}

Source: The Council of State Governments (1996-97, Table 810) lation of the world? About $6 \mathrm{~B}$ people (Information Please Almanac $1996,130-33) .{ }^{13}$ What is the population of the biggest countries?

\begin{tabular}{lr}
\hline China & $1,203 \mathrm{M}$ \\
India & $937 \mathrm{M}$ \\
U.S. & $264 \mathrm{M}$ \\
Indonesia & $204 \mathrm{M}$ \\
Brazil & $161 \mathrm{M}$ \\
Russia & $150 \mathrm{M}$ \\
Pakistan & $132 \mathrm{M}$ \\
Bangladesh & $128 \mathrm{M}$ \\
Japan & $125 \mathrm{M}$ \\
Nigeria & $101 \mathrm{M}$ \\
Mexico & $93 \mathrm{M}$ \\
Germany & $81 \mathrm{M}$ \\
Britain, France, and & $58 \mathrm{M}$ each \\
\multicolumn{1}{l}{ Italy } & \\
\hline
\end{tabular}

These 15 countries have a total population of $3,660 \mathrm{M}$, or well over half the population of all the world's 191 countries. The countries listed below, some will be surprised to learn, have small populations, even though they figure quite heavily in our national consciousness.

\begin{tabular}{lr}
\hline Canada & $28 \mathrm{M}$ \\
Israel & $5 \mathrm{M}$ \\
Ireland & $4 \mathrm{M}$ \\
\hline
\end{tabular}

How rich is the world? The Gross

World Product (the sum of the GDP's of all countries in the world) is about $\$ 30,000 \mathrm{~B}(1996,127-28){ }^{14}$ The U.S. GDP, of $\$ 7,000 \mathrm{~B}$, comprises about $23 \%$ of this, a far greater percentage than that of any other nation. Is the U.S. then the richest country in the world? Not in terms of per capita GDP (U.S. Department of Commerce 1996, 835). ${ }^{15}$ In those calculations, the richest nations are:

\begin{tabular}{lr}
\hline Switzerland & $\$ 38,000$ \\
Japan & 37,000 \\
Denmark & 27,000 \\
U.S. & 26,000 \\
Germany & 25,000 \\
\hline
\end{tabular}

Some of the poorest nations are:

\begin{tabular}{lr}
\hline India & $\$ 312$ \\
Ethiopia & 91 \\
Tanzania & 74 \\
\hline
\end{tabular}

Other quality of life comparisons reveal that life expectancy is greatest in Hong Kong (82.2 years), and lowest in Malawi (36.2), with the U.S., at 76.0 years, near the top (1996, 831). The nation with the highest military expenditure as a percentage of its GNP is North Korea, at 23\%; the U.S. spends $5 \%$, while Japan spends only $1 \%(1996,858)$. The U.S. is, unfortunately, far ahead of all competitors in the number of deaths by handgun per year, topping 9,000, while Great Britain, toward the bottom, had only 7 in the year measured (Wolff, et al. 1992, 294). ${ }^{16}$ The U.S. also holds the lead in rates of incarceration, particularly since the dismantling of the Soviet archipelago; our total of about $1.5 \mathrm{M}$ behind bars gives us a rate 4 times higher than that of Great Britain, and 10 times that of Japan or the Netherlands (U.S. Department of Justice 1995, 548; Wolff, et al. 1992, 296). ${ }^{17}$ Looking at working conditions, we find that workers in the U.S. spend more hours on the job each year than workers in any industrialized nation except Japan. Perhaps not coincidentally, the percentage of union membership in America is only $16 \%$, compared to Sweden's $85 \%$ (Wolff, et al. 1992, $146,153)$. When it comes to foreign aid, the U. S. spends less, in proportion to its national wealth, than nearly any other industrialized nation, as indicated in Table 3.

It may seem that the sort of figures mentioned thus far relate mostly to the "policy" section of the American Government course, and have little to do with the sections dealing with government structure and function. To the extent that this is the case, I would argue for giving greater priority to policy issues than is usually done. Students feel (and I agree) that policy is, after all, the payoff and culmination of all the structures, the outcome for which the structures exist. Certainly policy issues like health care press upon student attention more urgently than, say, the operating procedures 


\section{TABLE 3 Foreign Aid as Percentage of GDP}

\begin{tabular}{ll}
\hline Denmark & 0.96 \\
Norway & 0.87 \\
Netherlands & 0.81 \\
Sweden & 0.77 \\
France & 0.55 \\
Belgium & 0.38 \\
Canada & 0.38 \\
Australia & 0.36 \\
Luxembourg & 0.36 \\
Switzerland & 0.34 \\
Austria & 0.33 \\
Finland & 0.32 \\
Greece & 0.31 \\
Germany & 0.31 \\
Ireland & 0.29 \\
Japan & 0.28 \\
United Kingdom & 0.28 \\
Portugal & 0.27 \\
Spain & 0.24 \\
New Zealand & 0.23 \\
Italy & 0.15 \\
United States & 0.10 \\
Turkey & 0.07 \\
Korea & 0.03 \\
\hline
\end{tabular}

Source: OECD $(1997,68-69)$

of Congress, and so it makes pedagogical sense to use the former as an entree to the latter. This said, a sense of magnitudes and proportions can help students gain an understanding of structures, as well as policies. It helps, for instance, to clarify the relationship between the three supposedly equal federal branches to see that, of the $5 \mathrm{M}$ people who work for the federal government, over $99 \%$ work for the president, while less than $1 \%$ work for Congress and the Federal courts combined! It also gives some insight into governmental operations to see that most federal employees work for the defense department and the postal service, while most local employees are teachers (U.S. Department of Commerce 1996,345$).{ }^{18}$ It puts the system of federalism in perspective to learn that state and local governments, taken all together, spend as much money and employ 3 times as many workers as the federal government. And it provides a useful context for understanding constitutional issues of church and state to know that Americans declare their religious preferences to be: $60 \%$ Protestant, $24 \%$ Catholic, $2 \%$ Jewish, $6 \%$ Other, and $8 \%$ non-religious (1996, 70). ${ }^{19}$

It is certainly not my argument that we should replace thoughtful and theoretical analysis with mindless number crunching. (I am, after all, the political philosopher in our department, and my colleagues will be amused to find that I, of all people, have written an article on the importance of numbers!) To the contrary, I think significant and interesting data, properly used, can prompt questions that go beyond the numbers themselves. Why is the incarceration rate so high in the U.S., the income gap so great between Tanzania and Switzerland, and life expectancy so low in Malawi? Do these figures represent fate, or can something be done to change them?

I welcome suggestions concerning better ways to find and present significant data. The numbers used herein are intended to be more illustrative than definitive. The best solution would be to have this task done for us by textbook writers and publishers. Until that happens, however, I recommend that instructors spend a few hours in the library reference section in search of choice nuggets for class use. We should have confidence in our own abilities to recast and juxtapose data in useful ways, and to round them off for simplification. So what if we are off a few million or billion here or there? Even if we are, it will be better to get students thinking actively and critically, in terms of estimates and rough calculations, than to allow them to remain passive consumers (or nonconsumers) of boring, inert numbers.

\section{Notes}

1. The exact figure for world military ex penditures for the year 1993 is $\$ 868 \mathrm{~B}$. This represents a decline from $\$ 1,234 \mathrm{~B}$ in 1985 . (Hereafter I will use $\mathrm{B}$ for billion and $\mathrm{M}$ for million, and will avoid trillion altogether.)

2. These happened to be the 3 textbooks at hand. My comments are not intended to reflect on the quality of these books in any respect other than the matter of charts and data. Nor am I aware of any texts that do a better job with the data, though I would be happy to hear of some.
3. This publication has the additional merit that nearly all of its information is free of copyright restrictions, allowing it to be photocopied as needed for class use. The paperback edition was listed at \$28 in 1995. Computer disc editions are also available.

4. Federal expenditures for 1996 (estimated) are listed as $\$ 1,572 \mathrm{~B}$. State and local government expenditures are shown only up until 1993 , and these are $\$ 743 \mathrm{~B}$ and $\$ 685 \mathrm{~B}$, respectively $(1996,297)$. I have estimated higher state and local figures to reflect current expenditures, and have rounded off the whole set of numbers for pedagogical purposes.

5. The U.S. Gross Domestic Product for 1995 is listed as $\$ 7,245 \mathrm{~B}$.

6. I am indebted to my colleague Richard Flickinger for introducing me to this valuable source of intergovernmental comparisons. The figures account for taxation by all levels of government. I have converted the alphabetical listing to a rank order listing. I am aware that there is a large discrepancy between these figures, showing U. S. tax receipts to be $27.6 \%$, and my estimates showing U. S. federal and state governments to spend $\$ 3,200 \mathrm{~B}$ of a $\$ 7,000 \mathrm{~B}$ GDP, which would indicate a $45.7 \%$ tax rate. This discrepancy may be due in part to the fact that the OECD data are from 1994. Also, government tax receipts cannot be used to indicate government expenditures without taking account of the annual deficit. In any event, such an important comparison calls for further inquiry.

7. The estimated debt for 1996 is shown to be $\$ 5,207 \mathrm{~B}$. Many students, in my experience, are not aware of the difference between the annual deficit and the total debt, and are under the mistaken impression that "balancing the budget" means eliminating the debt.

8. Statistical Abstract $(1996,332)$ shows the following estimated federal budget for 1996 , in millions of dollars:

\begin{tabular}{lr}
\hline National Defense & $\$ 265,556$ \\
Social Security & 350,924 \\
Income Security & 228,342 \\
Medicare & 177,586 \\
Health & 121,211 \\
Education & 54,131 \\
Veterans Benefits & 37,748 \\
Transportation & 39,769 \\
Commerce and & $-10,744$ \\
$\quad$ Housing & \\
Net Interest & 241,059 \\
Other & 71,452 \\
Undistributed Offsets & $-42,268$ \\
Total Outlays & $\$ 1,572,411$ \\
(includes "Outlays not shown separately") \\
\hline
\end{tabular}

Detailed as it is, this breakdown is not fully satisfactory. Poverty-related assistance, for instance, is not listed separately, but is scattered throughout the other categories. "Income Security" refers not to poverty assistance but to federal employee retirement programs. Fortunately, poverty-related expenditures are brought together in a table on $\mathrm{p}$. 371 of the 1996 Statistical Abstract. There we learn that, for 1994, means-tested federal outlays totaled $\$ 246 \mathrm{~B}$, in addition to $\$ 99 \mathrm{~B}$ by state and local governments. The table lists in 
detail the amounts spent by the federal government for food stamps, AFDC, housing assistance, student loans, Medicaid, school lunches, job training, etc. Using this table, together with the one printed above, I have reconfigured categories and rounded numbers to arrive at the simplified presentation herein.

9. The Book of the States gives 1992 figures showing government employment at the state level to be $4.595 \mathrm{M}$ and, at the local level, 11.103M. (This chart also showed the numbers employed in different types of jobs: teachers, police, etc.) Statistical Abstract shows federal civilian employment for 1995 to be $2.94 \mathrm{M}$. To this must be added military employment, shown to be $1.7 \mathrm{M}$ for the year 1993 $(1996,357)$. In the simplified table that I have constructed from these number, the biggest "reach" was to round off the military at $2 \mathrm{M}$.

10. A couple of years ago I used this book in class. It consisted almost entirely of vivid graphs and charts comparing the U.S. to other nations in a whole variety of categories, including economics, education, health, politics, leisure, (and even sex, though I forbade my students to read that chapter!). This book illustrates well the main theme of my essay, since the selected points of information were significant, interesting, and well presented. I have not used it recently, however, since it has not been updated, and, more importantly, because it does not clearly indicate its sources and assumptions. With those reservations in mind, I will cite that source herein. It indicates that the U.S. percentage of government employees to total workforce is $14.4 \%$, a figure which ranked the U.S. far down the list of countries in terms of the size of government. I was unable to determine, however, the year of the report or assumptions concerning the total workforce.

11. Figures are for 1994, and include prison populations serving sentences of one year or more.

12. Undoubtedly, courses in comparative government do far more to compare crossnational data than do courses in American government, and some might think that the division of labor principle dictates that we assign such tasks accordingly. I have reservations about this reasoning, however. Since American government is the only political science course taken by many undergraduates, we are missing a great educational opportu- nity if we do not introduce such concepts in that course. Another problem with such a division of labor is that it is only in the light of comparison that we fully comprehend our own American government. (The logical conclusion to this point is that the introductory American and comparative government courses should be combined, which I believe should happen).

13. World population is listed, as of July, 1994 , at $5,643,287,771$. All population figures come from this source. I have rounded all country figures to the nearest million.

14. This interesting figure is shown to have been $\$ 29,000 \mathrm{~B}$ in 1993

15. All GDP per capita reports are for 1994. Figures for the richest nations are rounded to the nearest thousand. Figures for the poorest nations are as printed!

16. The figures are from 1988 , but the source is not mentioned.

17. Data from 1994 show a total population of 1,475,329 in all federal and state prisons and jails. A chart shows a dramatic increase from about 300,000 in 1980 to over one million (in prisons) in 1994 (U.S. Department of Justice 1995, 555).

18. The 1995 civilian employment by the federal government is listed as $2,918,674$. Of these, 28,993 work for and in the judicial branch, and 33,367 work for and in the legislative branch. This table also gives a detailed breakdown of totals within the executive branch, and across the years 1990 to 1995 . Agencies employing the greatest number of civilians are the defense department with 830,738 and the postal service with 845,393 .

19. Between 1967 and 1994, the percentage of Protestants decreased from $67 \%$ to $60 \%$, the percentage of Catholics and Jews remained fairly constant, "Other" grew from $3 \%$ to $6 \%$, and "None" grew from $2 \%$ to $8 \%$.

\section{References}

The Council of State Governments. 1996-97. The Book of the States. Vol. 31. Lexington, $\mathrm{KY}$.

Edwards, George C., Martin P. Wattenberg, and Robert Lineberry. 1996. Government in America. 7th ed. New York: Harper Collins.

Information Please Almanac. 1996. Boston: Houghton Mifflin.

Janda, Kenneth, Jeffrey M. Berry, and Jerry Goldman. 1993. The Challenge of Democracy. 3rd ed. Boston: Houghton, Mifflin.

Mann, Sheilah. 1996. "Political Science Departments Report Declines in Enrollments and Majors in Recent Years." PS: Political Science and Politics 29(3): 527-33.

OECD Information Management and Publication Service. 1997. OECD in Figures: Supplement to the OECD Observer 206 (June/July).

Patterson, Thomas E. 1996. The American Democracy. 3rd ed. New York: McGraw Hill.

U.S. Department of Commerce. 1996. Statistical Abstract of the United States.

U.S. Department of Justice. 1995. Bureau of Justice Statistics: Sourcebook of Criminal Justice Statistics.

Wolff, Michael, Peter Rutten, Albert F. Bayers III, and the World Rank Research Team. 1992. Where We Stand: Can America Make It in the Global Race for Wealth, Health, and Happiness? New York: Bantam Books.

\section{About the Author}

William I. Buscemi is professor of political science at Wittenberg University, where he has received the Alumni Award for Distinguished Teaching. He teaches in the areas of American politics and political theory, and his research interests focus on postmodern and pragmatic liberalism. His email address is buscemi $@$ wittenberg.edu. 